\title{
"Ninguém" é o nome do autor: Leonardo Gandolfi e Ana Martins Marques sobre a Odisseia
}

Filipe Manzoni ${ }^{1}$

\section{A astúcia de ninguém}

Uma série de autores e teóricos modernos já situaram a Odisseia como uma viagem que se dá em estreita relação com uma jornada de retomada de um nome próprio. François Hartog, em seus estudos a respeito de um verdadeiro paradigma do moderno conceito da história presente na obra homérica, diz que, ao fim da jornada, "ele (Ulisses) recuperará, para terminar, sua identidade e, antes de tudo, seu nome (ninguém poderá ser de novo Ulisses)" (Hartog, 2004, p. 26). Tanto quanto uma epopeia de retorno à casa, a Odisseia pode ser lida como uma epopeia da retomada do nome, bem como do poder de nomear sua própria história. O perigo maior para seu protagonista, morrer no mar e ser esquecido, revelar-se-ia, assim, como um pavor de ter seu nome esquecido e de não ser quem nomeia sua história.

Diversos trechos do relato tensionam essa chave de leitura, sendo possivelmente o mais célebre o momento no qual a astúcia do herói se torna curiosamente homônima da designação de sua ausência de nome próprio: o episódio do ciclope Polífemo. No episódio em questão, ao ter seu nome indagado pelo gigante, Ulisses se diz ninguém, ou, em grego, Oũtis. A eficácia do estratagema de Ulisses se deve a uma mudança de acento, pela qual Oũtis, passa a soar não como um nome próprio, mas como oú tis, não tanto "ninguém" quanto "não alguém", conforme aponta Heller-Roazen no capítulo de abertura de seu No one's ways: an essay on infinite naming (Heller-Roazen, 2017), compondo-se do prefixo negativo oú e o pronome tis, "alguém" ou "um" (jogo perdido na tradução para o português "ninguém", e que estaria mais próximo de um "nem um" que arruinaria a naturalidade da frase "ninguém me feriu", proferida pelo ciclope).

\footnotetext{
${ }^{1}$ Doutorando em literatura na Universidade Federal de Santa Catarina (UFSC), Florianópolis, SC, Brasil. (Dorcid.org/0000-0001-8987-7965. E-mail: manzoni@ poetic.com
} 
O jogo, porém, não acaba aí, na medida em que o atributo mais célebre do herói grego, sua astúcia, é ainda repetida, em resposta, pelos companheiros do gigante que poderiam acudi-lo. Tomemos a explicação de Heller-Roazen: “Perguntado se há um 'não alguém' ( $m \bar{e}$ tis) fazendo mal a seu amigo, os vizinhos empregam uma expressão interrogativa de sonoridade quase idêntica à palavra méttis, que é 'astúcia'" (Heller-Roazen, 2017, p. 8, tradução nossa). Um dos epítetos mais célebres de Ulisses, sua astúcia é, portanto, repetido pelos vizinhos do gigante como a própria designação de ser "não alguém". Polífemo é cegado ao mesmo tempo por um "não alguém", mế tis, mas também pela esperteza e astúcia, métis, de Ulisses.

Ulisses, porém, tão astuto quanto soberbo, revela seu nome verdadeiro ao gigante quando já está fora de seu alcance, momento no qual Polífemo, munido do nome do herói, roga a Poseidon que realize sua vingança, motivo pelo qual o deus irá dificultar tanto sua volta para casa. Não deixa de ser curioso, portanto, a forma pela qual, enquanto "ninguém", Ulisses poderia voltar para casa anonimamente. É a partir de uma retomada de seu nome que seu destino errante é determinado pelo deus dos mares.

Os mesmos termos retornam ainda quando o herói é indagado por outro personagem que o abrigará, não mais o terrível Polífemo, mas, desta vez, o rei da corte dos Feácios, Alcínoo. Nessa ocasião, Ulisses recusa também sua identidade, ao passo que o rei o interpela dizendo que "Ninguém (oú tis) é completamente sem nome". O herói não se apresenta, porém, imediatamente, e só revela seu nome após a célebre cena do canto do aedo dos Feácios, Demócoco.

Na cena em questão, Demócoco canta alguns dos célebres feitos de Ulisses durante a guerra de Tróia sem saber que está na presença deste, ao que o herói começa a chorar, e em seguida a narrar, por si mesmo, e em seu próprio nome, sua história. François Hartog ressalta, retomando a leitura da filósofa alemã Hannah Arendt, o quanto "nesta cena que põe face a face o aedo e o herói, que escuta a narrativa de suas próprias ações, Hannah Arendt via o começo, ao menos do ponto de vista poético, da categoria de história" (Hartog, 2003/2015, p. 67).

As lágrimas de Ulisses trazem, assim, uma recusa a se ver como personagem histórico, conforme Hartog já havia ressaltado em um texto anterior: 
Ulisses encontra-se na penosa posição de ter de ouvir a narrativa de suas façanhas na terceira pessoa como se estivesse ausente, como se estivesse morto. Ele se vê no lugar ocupado pelo morto na narrativa histórica. A epopeia e a história pressupõem a morte, ou melhor, tecem-na com suas palavras, como uma mortalha que, recobrindo o rosto dos mortos, faz deles justamente mortos (Hartog, 1998/2003, p. 26).

A cena que marca, segundo Arendt e Hartog, o início da categoria histórica é, nesse sentido, a mesma que marca um gesto eminentemente autoral: Ulisses toma a palavra como que para contar, por si mesmo, sua história. Para autorizá-la, se retomarmos a etimologia esclarecida por Giorgio Agambem a respeito do sentido latino de um "autor": "quem intervém no ato de um menor (ou quem, por algum motivo, não tem a capacidade de realizar um ato juridicamente válido), para lhe conferir o complemento de validade de que necessita" (Agamben, 2000/2008, p. 149). Autorizar, portanto, coloca-se, por parte de Ulisses, como um mesmo gesto de assumir seu nome próprio em primeira pessoa e tomar posse de sua história.

O mesmo gesto, portanto, de tomar a palavra para si e fazer sua história em seu próprio nome pode ser lido a um só tempo como uma passagem da terceira pessoa para a primeira - isto é, de um oú tis ${ }^{2}$ para um "eu, Ulisses" -, como uma reatualização do histórico no contemporâneo do discurso e, ainda, como uma transformação de um personagem em um autor. Cremos que o tensionamento desses desdobramentos possíveis é precisamente o que está em jogo em dois blocos de poemas de dois poetas brasileiros contemporâneos: Leonardo Gandolfi e Ana Martins Marques. Interessa-nos observar o quanto esse mesmo núcleo "autoral-histórico-pessoal" parece ser reaberto por Gandolfi e por Marques de maneira a desestabilizar novamente esse tema tenso da Odisseia: a retomada do nome e a autorização do relato.

Voltaremos nossa discussão, assim, para três tópicos: inicialmente, para a poesia de Gandolfi; em segundo lugar, para uma contraposição crítica na qual retomaremos a importância da Odisseia como modelo para pensar a própria história literária ocidental; em terceiro, para os

\footnotetext{
${ }^{2}$ Uma "não pessoa", se seguirmos a designação de Benveniste (1995).
} 
poemas de Ana Martins Marques - que parecem desdobrar diferentes aspectos dessa retomada do nome próprio por parte de Ulisses. Em seguida, concluiremos nosso percurso a partir de uma releitura dessa aproximação entre o nome, a autorização e a história a partir de um paradigma do contemporâneo tomado como demora deliberada da autorização de um nome, mais precisamente, do nome do autor.

\title{
Problemas sobre o nome do autor
}

\author{
Samuel Butler \\ que verteu entre outros a Odisseia \\ para prosa tem uma tese curiosa. \\ Segundo ele, Nausícaa, a mocinha \\ que dá guarida a Ulisses \\ quando ele está em maus lençóis \\ é na verdade o próprio Homero. \\ Cada linha sobre a volta para casa do herói \\ foi composta por ela. \\ A filha do rei Alcino \\ e suas escravas lavando roupa. \\ Os panos secam enquanto elas tomam \\ banho jogam bola cantam. \\ agora porém, ainda estão lanchando. \\ A coisa terminará quando \\ Ulisses surgir na praia nu \\ as meninas em roupas de banho correndo \\ menos Nausícaa (Gandolfi, 2015, p. 31).
}

O poema de Leonardo Gandolfi, "[Samuel Butler]", abre a série "Piquenique", presente no terceiro volume de poemas do escritor, Escala Richter, de 2015. Gandolfi, cuja obra foi lida diversas vezes a partir de uma problemática do autoral e da apropriação - em especial graças à obra A morte de Tony Bennet, de 2013 -, parece, com "Piquenique", ao mesmo tempo se aproximar e se afastar da problemática autoral, levando a discussão para um contexto diferente daquele de seu segundo livro, marcado pelas apropriações e colagens.

Sua série de poemas se volta para a "curiosa" tese de Samuel Butler a respeito da autoria da Odisseia segundo a qual a obra teria 
sido escrita não por Homero, mas sim por uma mulher, jovem e strong headed - para tomarmos a expressão de Butler - centenas de anos após a data comumente estimada para a escrita da Ilíada. O estudo de Butler - The authoress of the Odissey, where and when she wrote, who she was, the use she made of the Iliad, and how the poem grew under her hands (Butler, 1922) -, que perpassa uma série de argumentos geográficos e filológicos, mas também uma longa consideração a respeito do protagonismo feminino na obra, busca, mais do que apenas propor uma autoria feminina, mapear os traços por ela deixados (provável localização, vivências, idade etc.) ao cabo do que o autor sugere uma figuração para essa autora em uma personagem da própria Odisseia: Nausícaa, filha do rei Alcínoo.

Se os argumentos de Butler são francamente questionáveis em especial em suas constatações de uma "feminilidade" no texto homérico -, sua problematização da autoria da Odisseia não deixa de ser interessante. Segundo o autor, a Odisseia teria sido escrita ao menos um século após a Ilíada (Butler, 1922, pos. 3979-4001), sendo impossível que os textos fossem escritos pela mesma pessoa. Uma priorização sutilmente diferente parece ser a que está em jogo no poema de Leonardo Gandolfi.

Primeiramente, caberia ressaltar o quanto, desde seu título, "Piquenique", Gandolfi parece inserir todos os poemas de seu bloco dentro de uma mesma cena, retirada diretamente da Odisseia: o momento lúdico de Nausícaa e as suas escravas após lavarem roupa. A abertura do poema de Gandolfi é, nesse sentido, quase didática: faz uma breve apresentação da tese de Samuel Butler, para, a partir daí, empreender uma rápida descrição da cena do piquenique propriamente dito. Gandolfi parte do encontro do herói com a representação ficcional do real escritor da epopeia (se seguirmos a teoria de Butler), colocando o problema de quem conta a história a partir de um face a face entre personagem e autor.

Particularmente, interessa-nos ressaltar o recorte temporal escolhido por Gandolfi para situar seu poema. A partir do décimo verso - após a descrição da tese de Butler e apresentação da cena do piquenique -, o poema faz uma autorreferência dêitica à sua própria temporalidade, "agora, porém, ainda estão lanchando", sobrepondo o tempo do piquenique de Nausícaa e das escravas à própria temporalidade de leitura do bloco de poemas. Essa 
contemporaneização entre a instância de discurso que materialmente lemos na obra de Gandolfi e a cena homérica incorre em algumas implicações interessantes que parecem sugerir uma articulação diferente das que comumente são lidas entre a Odisseia e o conceito de história.

$\mathrm{O}$ "agora" do poema se estrutura como uma demora distendida e, ao mesmo tempo, uma antecipação do fechamento da cena: "a coisa", cujo fim é também o encerramento dessa temporalidade do agora, é a própria atividade do piquenique que dá título ao bloco. Dessa maneira, flagramos nos poemas uma contemporaneização que, para além das marcas dêiticas temporais, também é tematicamente referida. $\mathrm{O}$ encontro de Nausícaa com Ulisses (que passa praticamente em branco no livro de Samuel Butler) coloca em cena um problemático encontro do personagem heroico com o autor de sua história desde uma instância presente ou contemporânea.

A mesma questão ainda aparece no segundo poema da série, no qual Gandolfi diz que "O caminho / que vai da princesa / a Homero tem pouco a ver / com autobiografia / biografia ou bobagens do tipo" (Gandolfi, 2015, p. 32). Essa espécie de comentário a respeito da tese de Samuel Butler parece de imediato ressalvar a cena do encontro entre Nausícaa e Ulisses de um lastro factual histórico-filológico que está no centro do argumento de Butler. O que interessa no encontro não é qualquer lastro possível, mas, antes, as questões que estão implicadas nessa retomada da cena, contemporaneamente, pela poesia de Gandolfi.

Há, conforme adiantamos, outro episódio homérico no qual Ulisses encara alguém que está contando sua história (e que possui uma fortuna crítica que nos interessa particularmente): a cena do aedo dos Feácios. Se nos voltarmos para a leitura que François Hartog e Hannah Arendt propõem para a cena, é curioso o fato de nenhum dos dois autores chamar a atenção para a problemática autoral que está ali também presente: Ulisses se encontra com a pessoa que estaria contando a sua própria história (nesse caso, Demócoco) e intervém nesse ato. Se Ulisses chora por se ver referido como personagem histórico, mas não vê problemas em recontar, por si mesmo, sua própria história, é possível que suas lágrimas digam mais de um problema do autoral, ou da ordem de 
uma autorização da narração do que simplesmente de sua historicização.

Tomemos ainda o desfecho da cena: após chorar, Ulisses toma a palavra, elogiando o canto do aedo e sua descrição tão precisa, ou "mesmo 'exageradamente' precisa" (Hartog, 2003, p. 23) dos fatos, identifica-se finalmente e faz seu próprio relato dos acontecimentos que materialmente constituem o grande "relato de viagem" da Odisseia. Se, por definição, o aedo não configuraria jamais um "autor", porque seu canto provém das musas, Ulisses parece se colocar em uma posição um tanto diferente, ambivalente entre um autor e um historiador. Cabe retomarmos a análise de Hartog:

Ulisses não é um aedo. Pois não é a Musa que o ensina: ele suportou em seu corpo e viu com seus próprios olhos tudo que conta. Fala na primeira pessoa, dando-se a si mesmo como única garantia do que diz (donde também a questão da mentira), enquanto o aedo recorre sempre à terceira, pondose sob a autoridade das Musas que, elas sim, estava presentes (Hartog, 1996/2004, p. 40).

A própria discussão refutada pelo poema de Gandolfi - se a tese de Butler se colocaria sob a chave de uma biografia, autobiografia ou "bobagens do tipo" - reveste-se, assim, em uma maneira de não encerrar em uma resposta ou em um lastro histórico específico o "quem autoriza" a história. Tanto quando está frente a frente com Demócoco como quando encara Nausícaa, Ulisses encara figuras pretensamente autorais de sua história. Se no caso da cena do aedo, Ulisses efetivamente toma a palavra (e retoma seu nome) para narrar a história, esse "desfecho" não se dá no caso de Nausícaa: o herói não se identifica, mantendo o suspense da autorização ainda tenso, trazido precisamente pelo "agora" do texto de Gandolfi.

A história de Ulisses não se configura mais, portanto, como um embate entre o presente e o histórico, mas sim como uma desautorização aberta em sua janela de contemporaneização. O que era um núcleo substantivo estático (autor, histórico, presente) desdobra-se em um núcleo verbal (autorizar, historicizar, contemporaneizar), de maneira que todos esses conceitos são tomados em sua figuração dinâmica, em sua operação de reconfiguração nessa temporalidade distendida de demora de uma reautorização. 


\section{História literária: de Tróia para casa e de lá para o fim do mundo}

Nosso ponto inicial para situar a Odisseia como uma jornada de fundação de uma experiência histórica ao mesmo tempo em que uma reconquista do nome se deu a partir das proposições do historiador francês François Hartog. A obra de Hartog se faz ainda especialmente interessante na medida em que propõe uma releitura de uma das mais canônicas asserções a respeito de uma experiência literária da história, o capítulo de abertura do célebre Mimesis de Erich Auerbach, "A cicatriz de Ulisses" (Auerbach, 1995 p. 9-30). De fato, o capítulo de Auerbach possui quase que uma fortuna crítica autônoma, dada sua repercussão e importância para a literatura comparada mundial.

Hartog retoma os apontamentos de Marcel Detienne para reler o texto de Auerbach, ressaltando o quanto o diagnóstico do filólogo alemão - em seu resumo, "do lado de Homero, teríamos, personagens totalmente superficiais e material legendário, enquanto do outro [a leitura de Auerbach do sacrifício de Isaac no Antigo Testamento] está presente a historicidade" (Hartog 2015, p. 67) - incorreria em uma patente simplificação da temporalidade presente na Odisseia.

Segundo Hartog, a formulação de Auerbach da temporalidade inerente aos personagens homéricos se aplicaria perfeitamente a Aquiles - "para ele, todo dia é o primeiro" (Hartog 2015, p. 67) -, porém, no que toca a Odisseia, a proposição de uma temporalidade onde tudo é presente não se aplicaria de maneira assim tão direta. Hartog (2015, p. 70) diz, sobre a Odisseia e a Ilíada, o quanto "há deslocamento temporal de um poema para outro". A mesma distância que em Samuel Butler se situa em um nível filológico e cronológico (esteja este correto ou não) coloca-se na leitura de Hartog em uma distinção da ordem da experiência literária. Tomemos o texto de Hartog (2015, p. 70-71):

Desde a abertura da Odisseia, estamos de fato no após, na memória do acontecimento e na lembrança dos lutos e dos sofrimentos suportados. Ponto de referência compartilhado, e em seguida disputado, a guerra de Troia de fato permaneceu, até entre os modernos, como este acontecimento "axial" em relação ao qual a Odisseia, que conta vários episódios da guerra, já está em posição de história. 
A conclusão de Hartog (muito menos sistemática e clara, mas consideravelmente mais nuançada que a de Auerbach) é a de que a temporalidade da Odisseia se encontraria em uma situação limítrofe, na medida em que Homero não "pode mais simplesmente justapor e não sabe ainda cronologizar" (Hartog, 2015, p. 82). A Odisseia se inseriria, assim, em um limite tênue entre o não mais puro presente, mas ainda não propriamente histórico teleológico.

A possibilidade de flagrar a Odisseia em uma temporalidade limítrofe entre um após próprio do histórico e uma contemporaneidade caracterizada pela demora do estabelecimento de uma linha teleológica ainda pode ser relida em um cenário crítico consideravelmente mais contemporâneo (no sentido corrente da palavra), na medida em que ressoa em uma discussão proposta por Marcos Siscar em seu mais recente livro, De volta ao fim (Siscar, 2016).

Nos dois capítulos que abrem seu livro - "O tombeau das vanguardas: a 'pluralização das poéticas possíveis' como paradigma crítico contemporâneo" (Siscar, 2016, p. 19-40) e "A alavanca da crise: a poesia 'pós-utópica' de Haroldo de Campos" (Siscar, 2016, p. 42-67) -, Siscar dialoga diretamente com a obra de Haroldo de Campos no que toca uma teoria do contemporâneo e do histórico precisamente a partir da figura de Ulisses e de sua "última viagem".

Em "O tombeau das vanguardas", Siscar se volta para o célebre texto crítico de Haroldo de Campos, "Poesia e modernidade", situando-o como um tombeau das vanguardas, na medida em que este fecha o ciclo concretista como uma espécie de última vanguarda poética possível, a partir da qual toda poesia se daria segundo o diagnóstico de um "pós-utópico" (Siscar, 2016, p. 23). Siscar evidencia o quanto Haroldo parece replicar alguns dos mesmos pressupostos que pretende superar, na medida em que seu diagnóstico de uma "pós-vanguarda" se mantém, ainda, como um movimento eminentemente vanguardista de negação do passado: "O espírito de substituição histórica (nosso desejo de 'virar a página') continua visível na obsessão por elementos que marcam a posteridade (o pós-utópico, o pós-moderno, a póspoesia, a pós-história etc.)" (Siscar, 2016, p. 30).

É a um diagnóstico muito semelhante que Siscar chega em "A alavanca da crise: a poesia 'pós-utópica' de Haroldo de Campos", quando se volta, não mais para a produção crítica de Haroldo, mas 
para sua trajetória poética. Ao se referir à obra $A$ educação dos cinco sentidos, Siscar nos fala de uma evidente "necessidade de recomeçar" (a expressão é de Siscar) por parte da obra de Haroldo, um "esforço muito evidente de reescrever as antigas oposições, de incorporar o antagonismo num gesto dialético e estratégico de superação dos contrários" (Siscar, 2016, p. 52), precisamente o mesmo modelo de substituição histórica que Siscar propunha como operadora de "Poesia e modernidade".

É a partir desse ponto comum entre os dois ensaios que Siscar lança a proposição que será central para nossa argumentação, na medida em que identifica o topos da viagem como um dos temas privilegiados na obra de Haroldo. A viagem, esse "princípio organizador" (a expressão é de Siscar) da obra de Haroldo aparece na crítica de Siscar a partir da sintomática retomada do ilustre marinheiro, Ulisses. Marcos Siscar aponta para o quanto esse "velho viajante" aparece como uma "figura-chave" na poesia de Haroldo no contexto pós-utópico: "Creio que a figura que congrega, em Haroldo, todos esses elementos (da viagem, do heroísmo e da relação com o fim) é a do épico Odisseu, o astucioso que é também o ousado, o soberbo, exemplo máximo da húbris." (Siscar, 2016, p. 54).

Siscar empreende, assim, uma leitura do poema "Finismundo: a útima viagem" - cujo título não poderia ser mais sintomático - de Haroldo de Campos. Cabe aqui, retomarmos um fragmento de sua leitura:

Finismundo retoma a tópica tradicional da morte de Odisseu, não contada pela Odisseia, mas apenas referida, graças à profecia de Tirésias (thanatos ex halós, "morte que provém do mar salino", na tradução do próprio Haroldo) [...] Haroldo aborda o mítico silêncio relacionado à morte do herói, retomando-o a partir da audácia de reiniciar a viagem (Siscar, 2016, p. 54-55).

O resgate da viagem de Ulisses se converte, assim, em uma alegoria da mesma substituição histórica da qual o crítico falava, isto é, da passagem da "época dos combates (a vanguarda) para a época da pacificação (o pós-utópico)" (Siscar, 2016, p. 57). A poesia de Haroldo se coloca sob o signo de uma necessidade de retomar a viagem, não mais na chave de um retorno para casa, mas, sim, como uma partida para o destino desconhecido, para o fim do mundo. 
Trata-se, nesse sentido, de uma necessidade de retomada da história após a constatação de seu fim.

A retomada de Haroldo se ampara, porém, não apenas sobre uma tradução, mas sobre uma deliberada interpretação da profecia de Tirésias. O mesmo François Hartog, em uma de suas releituras da Odisseia, ressalta o quanto o thanatos ex halós é, antes de tudo, uma profecia ambígua, podendo significar "uma morte 'vinda do mar' ou 'longe do mar'. Os dois sentidos são possíveis" (Hartog, 2004, p. 47).

É evidente que essa ambiguidade, em especial por conta das divergências entre as diversas retomadas da Odisseia pela literatura mundial, não escapava a Haroldo. Seu Ulisses que parte de novo, rumo ao Finismundo, é antes de tudo uma escolha pelo Ulisses que Hartog situa em sua face "moderna", curiosamente apresentada como "antípoda de Ulisses" por Hartog (2004, p. 52), na medida em que, segundo o historiador francês, o personagem homérico "não quer lembrar-se senão do dia do retorno" (Hartog, 2004, p. 27).

Tanto o poema "Finismundo" quanto o conceito de "poesia pósutópica" de Haroldo são apontados por Siscar como uma planificação pós-histórica que se recusaria à "nomeação das forças estruturantes do presente", isto é, uma decorrência de "um desejo de pacificação do campo conflituoso do presente" (Siscar, 2016, p. 21) por parte de Haroldo. Ambos os autores mantêm, porém, o nome do herói assegurado como testemunha autorizada de sua própria história. É nesse ponto que a cena se reconfigura nos poemas de Gandolfi. Neles, o nome de Ulisses ainda não está assegurado, pois a cena em questão é anterior à sua retomada: o momento que o herói, ainda um "ninguém", sai da praia e encontra Nausícaa. Cremos, ainda, que um segundo deslocamento é possível ao nos voltarmos para a poesia de Ana Martins Marques, na qual encontraremos uma problematização semelhante à de Gandolfi, porém a partir da mesma cena priorizada por Haroldo de Campos: o retorno de Ulisses para casa.

\section{O fim do mundo na beira da praia}

O livro de estreia de Ana Martins Marques, A vida submarina (Marques, 2009), possui, ao longo de seus mais de cem poemas, apenas duas séries que recorrem a um título sequencial: "Memória" (que mantém ecos evidentes com o conceito de história, mas à qual 
não nos voltaremos aqui), composta de dois poemas, e "Penélope", uma série de seis poemas dispersos ao longo dos últimos três blocos do volume. É marcante que, seja em referências mais diretas - como em "A outra noite", em que Penélope é efetivamente nomeada -, seja em marcas mais sutis - que vão da noção de um "marinheiro grego" às diversas imagens de navegação -, Ana Martins Marques parece incorrer também em outros poemas em diversas modulações possíveis para esse mesmo casal central homérico, Penélope e Ulisses.

De início, é interessante ressaltar o fato de que quem assume o centro da questão do histórico em Ana Martins Marques não é mais Ulisses, mas Penélope. No lugar da viagem como metáfora estrutural do histórico, Penélope traz uma segunda metáfora (não menos clássica): a atividade de tecer. $\mathrm{O}$ texto enquanto tecido, recorrente em toda uma série de derivações de sentido já estáveis na língua, que vão da "trama narrativa" até a "linha argumentativa", desdobra-se em uma alternativa ao conceito de história enquanto viagem, e suas implicações parecem ir justamente contra o "desejo de 'virar a página'" (para retomarmos a expressão de Siscar) aí implicado.

Em segundo lugar, cabe observar o quanto a noite, o momento do "destecimento" de Penélope, é colocada, pelos poemas de Marques, constantemente sob o signo da falha. Não se trata de uma imagem da espera heroica, imbatível e infalível, mas de uma que está sujeita a um campo do contingente. Tomemos, assim, o segundo poema da série:

\section{Penélope (II)}

A trama do dia

na urdidura da noite

ou a trama da noite

na urdidura do dia

enquanto teço:

a fidelidade por um fio (Marques, 2009, p. 105).

Trata-se de um poema que apresenta uma estrutura dual, dada pelos primeiros quatro versos, que jogam com uma complementaridade inerente à atividade material da tecelagem: a relação entre a urdidura - conjunto dos fios longitudinais aos quais o fio da trama perpassa - e a trama. Essa complementariedade é trazida para o poema como uma imagem para a relação que se dá entre dia e noite na atividade de Penélope. Pensar o dia ou a noite como urdidura enquanto o outro define o fio da trama, converte-se 
em uma forma de situar dia $e$ noite (e suas atividades de tecer e destecer), não como uma oposição, mas como um mútuo atravessamento. Não existe, nesse sentido, "trama" sem essa complementariedade entre a urdidura e o fio, bem como a tessitura de Penélope, para durar, precisa englobar sua própria destruição.

"A fidelidade por um fio" lança mão da metáfora usual "por um fio", indicadora de um dado de fragilidade, para se reaproximar, novamente, da própria atividade de Penélope, na medida em que a fidelidade é, efetivamente, no contexto da tessitura da personagem homérica, um fio. É curioso que a "fidelidade por um fio", no poema de Ana Martins Marques, parece restituir a materialidade a uma metáfora já consolidada no português corrente, trazendo para o centro do discurso da espera a fragilidade da "tessitura" da história oficial.

Penélope, enquanto retrato da espera, revela, assim, estar à mercê das contingências - "por um fio" - e não assegura uma espera heroica e incansável. Ao deslocar a figura organizadora da história de Ulisses para Penélope, a "história" da viagem está, em Ana Martins Marques, sempre em risco. Essa imagem se torna ainda central na medida em que, conforme Hartog aponta na cena inaugural do embate com o histórico na Odisseia - as lágrimas de Ulisses frente ao aedo dos Feácios -, a recusa do herói em aceitar o discurso de Demócoco é uma recusa da "mortalha que, recobrindo o rosto dos mortos, faz deles justamente mortos" (Hartog 2003, p. 26) e, portanto, históricos.

Caberia, ainda, ressaltar o quanto essa aproximação converte imediatamente Penélope em uma imagem de resistência, isto é, em uma personagem que se recusa a tecer definitivamente o véu histórico. Hartog chega a chamar a atenção precisamente para isto, para o fato de que Penélope (assim como Ulisses, mas apenas em sua leitura "não moderna"), ao se recusar a terminar de tecer a mortalha, recusa-se ao estabelecimento da história, na medida em que não converte "a ausência (póthos) em 'passado'" (Hartog 2003, p. 20).

É sintomático ainda que o próprio livro, A vida submarina, se encerre pelo último poema da série "Penélope", onde, em quatro versos, Ana Martins Marques parece fazer ressoar todos os impasses do histórico que viemos abordando:

\section{Penélope (VI)}

E então se sentam

lado a lado 
para que ela lhe narre

a odisseia da espera. (Marques, 2009, p. 142)

Assim como no poema de Gandolfi, a temporalidade do poema de Ana Martins Marques se dá desde uma contemporaneização "e então se sentam" - na qual o discurso de Penélope é anunciado, mas ainda não enunciado. Mesmo no poema final de seu livro, portanto, a poeta parece deixar claro o quanto o espaço derradeiro para o tensionamento do conceito de história é ainda a abertura mesma de sua própria reformulação. Não interessa o que viria depois (temporalidade do Finismundo de Haroldo de Campos), mas, sim, o "agora" do contemporâneo.

"Penélope (VI)" retoma ainda, e novamente, o mesmo embate com o histórico que Hannah Arendt e François Hartog propõem a partir da cena do aedo dos feácios: Ulisses vai ouvir a Odisseia da espera, assim como ouviu os seus feitos narrados por Demócoco. Não se trata, porém, de se sentir morto, ou coberto pela mortalha de um personagem histórico, mas, sim, de ouvir uma outra história, uma que se passa durante sua viagem mas não depende desta. Não é Ulisses quem autoriza a Odisseia da espera.

Cabe, porém, determo-nos em um ponto curioso do poema de Ana Martins Marques que permitirá estabelecer uma ponte para retomarmos a poesia de Gandolfi. Mais do que uma "criação" em sentido estrito, os versos de "Penélope (VI)" são, antes, uma paráfrase quase direta da cena que se dá ao final do vigésimo terceiro livro da Odisseia. Lemos, assim, no texto homérico, no final do tricentésimo primeiro verso, "prós allílous enéponte" ("narraram um ao outro", em uma tradução livre), as aventuras e os dissabores do tempo decorrido da Odisseia. A reciprocidade "prós allílous", que passa quase despercebida na tradução da Odisseia de Manoel Odorico Mendes para o português, marca, efetivamente, a voz de Penélope narrando a "odisseia da espera" para o herói.

O deslocamento proposto por Ana Martins Marques retoma, nesse sentido, um fragmento direto da Odisseia (embora claramente negligenciado pelas traduções) incorporado ao texto. A mesma cena que nos serve, portanto, para desestabilizar a figura de Ulisses como personagem nomeador e autorizador de sua história na poesia de Marques, leva-nos de volta a uma problemática da autoria da própria Odisseia, na medida em que na cena na qual ambos se 
sentam para "narrar um ao outro" o tempo transcorrido é da "autoria" de Homero/Nausícaa, sendo apenas parafraseada, ou, talvez, acolhida, por Ana Martins Marques.

\title{
Nausícaa, Penélope e Polífemo
}

\author{
As aventuras de Nausícaa \\ e de suas coleguinhas escravas, distração \\ em tempos difíceis, têm chamado \\ minha atenção para tópicos realmente \\ importantes como hospitalidade e discrição. \\ Acolher é tudo, ainda mais quando \\ não se espera nada em troca, diz nosso herói \\ diante dos belos olhos da princesa. \\ Mas como o mundo não é feito apenas \\ de dificuldades envolvendo autoria \\ a esperança é que esses dois tópicos \\ me ajudem com alguns outros problemas, diz ele (Gandolfi, \\ 2015, p. 33).
}

No terceiro poema da série de Gandolfi, Ulisses toma a voz assim como na cena de Demócoco na Odisseia. Não se trata, porém, de uma retomada da autoridade para falar de sua própria história, mas, antes, de um elogio à hospitalidade (precisamente atividade que Nausícaa desempenha exemplarmente, cedendo a Ulisses as roupas de sua mãe e dando as indicações necessárias para que causasse uma boa impressão a Alcínoo). Antes de nos voltarmos, porém, para a questão da hospitalidade, cabe observar o quanto Gandolfi produz um interessante jogo de sobreposição e confusão de vozes no seu poema.

Juntamente com a voz de Ulisses, uma segunda voz parece ressoar na cena do piquenique. Seu tom é semelhante ao da voz que, nos dois primeiros poemas da série, descrevia a tese de Butler, apresentava o encontro entre Ulisses e Nausícaa e fazia deles sua apreciação crítica. Aqui, porém, ela é consideravelmente mais pessoal, lançando mão, em suas considerações, da primeira pessoa do singular, marcada pronominalmente desde o primeiro período do poema.

É curioso o quanto essa voz parece se sobrepor e se misturar à de Ulisses, na medida em que, após os cinco primeiros versos (nos quais ela figura isolada), ela é substituída pela voz do herói homérico, por 
mais três versos. Finalmente, a partir do nono verso, e até o final do poema, a temática (nos seus dois tópicos, a hospitalidade e a discrição) é retomada da fala da primeira voz (em primeira pessoa), mas em seu encerramento ela é atribuída a Ulisses.

Essa sobreposição gera uma nova nuance na problemática autoral, na medida em que a mesma voz que apresenta a cena (e que poderia ser associada a uma voz autoral de Gandolfi) se mistura com a do personagem precisamente no momento em que este se encontra face a face com a suposta imagem de seu autor. Mais do que apenas uma "cena" retirada da Odisseia, o que se esboça parece ser uma estrutura fractal de emolduramentos de discursos, na qual, dentro da obra de Leonardo Gandolfi, temos retratada uma sobreposição entre uma voz "autoral" e a de Ulisses, no momento em que este se encontra com a representação do verdadeiro autor da obra homérica (isto, é claro, se seguirmos a tese de Samuel Butler).

Sintomaticamente, essa mescla de vozes se dá como uma descaracterização da prevalência do autoral, ou, nas palavras do poema, dos "problemas envolvendo autoria". Tudo se passa, nesse sentido, como se o poema de Gandolfi abrisse um horizonte de desautorização pela sobreposição em fractal de vozes e autores entrecruzados de maneira a impossibilitar um mapeamento último dos limites entre essas instâncias.

Finalmente, se nos voltarmos agora para a noção da hospitalidade trazida pelo poema, novamente ecoarão algumas das mesmas questões que viemos abordando a respeito do conceito de história. Se retomarmos as reflexões de Jacques Derrida a respeito da hospitalidade, cumpre observar o quanto o filósofo nos situa a hospitalidade também como uma problemática do nome. Derrida diz: "A hospitalidade consiste em interrogar quem chega? Ela começa pela questão endereçada a quem vem" (Derrida, 2003, p. 25).

Na concepção estrita colocada pelo filósofo francês, o que se dá entre Nausícaa e Ulisses não seria uma questão de hospitalidade: o nome de Ulisses só será requisitado pelo rei Alcínoo (e, sintomaticamente só será respondido após seu choro, portanto, após a resolução do conflito com o histórico) e não por Nausícaa. Nesse sentido, Derrida (2003, p. 23) afirma que "a diferença, uma das sutis diferenças, às vezes imperceptíveis entre o estrangeiro e 
o outro absoluto, é que este último pode não ter nome”. É evidente que, no que toca ao encontro de Ulisses e Nausícaa, o que se passa é esse "momento-limite" no qual Ulisses ainda é um "outro absoluto", pois ainda pode não ter nome.

Nausícaa acolhe Ulisses, portanto, não a partir do pacto de cordialidade que marca um corte "anfitrião x estrangeiro" desde a indagação a quem chega por seu nome (e cujo fim aponta para a própria cadeia de termos que derivam de hostis, ambivalente entre hospedeiro e inimigo, analisada por Derrida). O que parece ser proposto através da hospitalidade de Nausícaa é uma noção de contato e de encontro que precede uma nomeação ou, ainda, a abertura de uma temporalidade que prescinde da autorização de um nome.

O episódio de Nausícaa, tal qual flagramos em Gandolfi, abre, portanto, uma nova possibilidade de leitura para a cena posterior do aedo dos Feácios (essa que marca o "começo da categoria histórica" para Dosse e Arendt). O momento em que o herói toma a palavra e fala em seu próprio nome é precisamente quando a "hospitalidade radical" de Nausícaa chega a um fim. François Hartog ressalta o quanto "assim que o próprio nome é recuperado e proferido, a narrativa de suas viagens apresenta-se como o meio de recompor-se" (Hartog, 2015, p. 79), de maneira que, até recuperar seu nome e narrar sua história, Ulisses (ou Oũtis) estava ainda em um limbo, conforme cabe retomar de um último trecho do historiador francês:

Ulisses mantém-se ainda nesse entremeio, onde ele não é mais e não é ainda Ulisses, ele que não conseguiu ainda pronunciar: 'Eu sou Ulisses'. Nesta distância sentida entre alteridade e identidade, o que vem instalar-se senão uma experiência do tempo? Não como agonia da finitude do homem, já que Ulisses entende-se e deseja-se mortal. Não se trata mais do tempo como fluxo, mas sim da experiência de uma distância de si consigo, que nomeio encontro com a historicidade (Hartog, 2015, p. 78-79).

É essa "experiência de uma distância de si consigo", ou esse encontro com a historicidade que não se define em uma "história", que cremos que está em jogo nessa "hospitalidade radical". Ao situar o agora do "Piquenique" em uma temporalidade prévia à reconquista do nome por parte de Ulisses 
e seu subsequente relato autorizado da história, a poesia de Gandolfi parece ler, no mesmo instante no qual Dosse e Arendt liam o início da categoria histórica, o início da categoria autoral.

A partir do instante em que o nome é reconquistado, isto é, a partir do momento em que o herói deixa de ser o "outro absoluto" porque diz "eu sou Ulisses", sua história está assegurada (e, em se tratando da Odisseia, a história literária ocidental está assegurada). Enquanto o herói ainda não possui nome, seja porque encara o verdadeiro escritor de suas jornadas, seja porque está ouvindo o relato de sua ausência, situamo-nos em modulações possíveis do limiar distendido dessa demora da reconquista de seu nome. Nessa temporalidade, não se trata tanto de uma única Odisseia, mas, sim, da abertura que se desdobra em novas formulações, como a Odisseia da espera ou a Odisseia imaginada por Nausícaa.

É essa abertura, esse embate não resolvido com a categoria do histórico através do nome, que se torna central para lermos, em Marques e Gandolfi, um paradigma do contemporâneo. O que parece estar em jogo nessa temporalidade de um contato que prescinde e precede a uma autorização é ser "contemporânea" apenas na medida em que é ainda a demanda por uma nomeação. Pensar, nesse sentido, o contemporâneo como um tempo ainda sem nome para si mesmo se desdobra em uma maneira de manter Ulisses em seu drama íntimo desde a cena que marca sua húbris, a soberba de gritar a Polífemo "eu sou Ulisses", selando assim seu destino.

Quando encara Nausícaa ou Penélope, Ulisses está em frente a duas das personagens-chave da história da reconquista de sua identidade: quem oferece sua hospitalidade sem exigir seu nome e quem tem o poder de tecer a mortalha que poria fim à espera, constituindo uma história. Enquanto ele as encara, portanto, o gesto que caracteriza a sua húbris ainda não está resolvido: Ulisses ainda é Outis, ainda não é autor de sua história. Reabrir a Odisseia a partir da questão do nome se coloca, portanto, como uma pluralização de relatos possíveis, o que parece interessar diretamente a Gandolfi e Marques. Não repensar a "última viagem", mas reencenar os contextos nos quais a própria viagem está ameaçada em seu drama mais íntimo.

Penélope e Nausícaa se convertem, assim, nas duas figuras que podem reparar o gesto de Ulisses, mas, sintomaticamente - o que 
é evidenciado pela marcação presente dos poemas "e então se sentam", no caso de Ana, "agora ainda estão lanchando", no caso de Gandolfi -, ainda não o fizeram (e, dessa perspectiva, são tão ameaçadoras quanto Polífemo). Do ponto de vista temporal, não se trata de um contemporâneo como resultado da história (uma "retomada" da viagem que reconhece que ela tenha tido um fim), mas de um que é a abertura de sua reformulação constante que não autoriza a categoria do fim. Penélope e Nausícaa permitem, nesse sentido, reencenar a Odisseia, essa narrativa fundadora da história literária ocidental, como um "texto" que é uma urdidura ainda sem arremate, isto é, como uma jornada de reconquista do nome que ainda não está concluída.

\section{Referências}

AGAMBEN, Giorgio (2000/2008). O que resta de Auwschwitz: o arquivo e a testemunha. (Homo Sacer III). Tradução de Selvino J. Assman. São Paulo: Boitempo.

AUERBACH, Eric (1995). Mimesis: la representación de la realidad en la literatura occidental. Tradução de J. Nillanueva y E. Ímaz. Mexico: Fondo de Cultura Económica.

BENVENISTE, Émile (1995). A natureza dos pronomes. In: BENVENISTE, Émile. Problemas de linguística geral I. Tradução de Maria da Glória Novak e Maria Luisa Neri. Campinas, SP: Pontes. p. 277-283.

BUTLER, Samuel (1992). The authoress of the Odissey: where and when she wrote, who she was, the use she made of the Iliad, and how the poem grew under her hands. New York: E.P. Duttton \& Company.

CAMPOS, Haroldo de (1997). Poesia e modernidade: da morte da arte à constelação. O poema pós-utópico. In: CAMPOS, Haroldo de. O arco-íris branco: ensaios de literatura e cultura. Rio de Janeiro: Imago. p. 243-269.

CAMPOS, Haroldo de (2004). Finismundo: a última viagem. In: CAMPOS, Haroldo de. Crisantempo: no espaço curvo nasce um. São Paulo: Perspectiva, p. 53-59.

DERRIDA, Jacques (2003). Anne Dufourmantelle convida Jacques Derrida a falar da hospitalidade. São Paulo: Escuta.

GANDOLFI, Leonardo (2010). A morte de Tony Bennett. São Pauo: Lumme. 
GANDOLFI, Leonardo (2015). Escala Richter. Rio de Janeiro: 7 Letras.

HARTOG, François (1998/2003). Os antigos, o passado e o presente. Tradução de Sônia Lacerda, Marcos Veneu e José Otávio Guimarães. Brasília: Editora da UnB.

HARTOG, François (1996/2004). Memória de Ulisses: narrativas sobre a fronteira na Grécia antiga. Tradução de Jacyntho Lins Brandão. Belo Horizonte: Editora da UFMG.

HARTOG, François (2003/2015). Regimes de historicidade: presentismo e experiências do tempo. Vários tradutores. Belo Horizonte: Autêntica.

HELLER-ROAZEN, Daniel (2017). No one's ways: an essay on infinite naming. New York: Zone.

MARQUES, Ana Martins (2009). A vida submarina. Belo Horizonte: Scriptum.

SISCAR, Marcos (2016). De volta ao fim: o "fim das vanguardas" como questão da poesia contemporânea. Rio de Janeiro: 7 Letras.

Recebido em 29 de setembro de 2017.

Aprovado em 14 de abril de 2018.

\section{resumo/abstract/resumen}

\section{"Ninguém" é o nome do autor: Leonardo Gandolfi e Ana Martins Marques sobre a Odisseia}

Filipe Manzoni

Nosso trabalho se propõe a uma leitura de duas retomadas da Odisseia presentes nas obras de dois poetas contemporâneos, Leonardo Gandolfi e Ana Martins Marques. Interessa-nos observar nos dois escritores uma problematização da tensão entre o histórico e o contemporâneo: tanto no bloco "Piquenique", de Gandolfi, quanto na série "Penélope", de Marques, o que parece estar em jogo é uma remontagem da epopeia homérica de maneira que o confronto com o histórico não esteja resolvido. Essa questão nos levará a uma retomada da importância da Odisseia como modelo para a estruturação de uma história literária e para o próprio conceito de história em si através de autores como François Hartog, Erich Auerbach e, num contexto mais recente, Haroldo de Campos e Marcos Siscar. Buscamos ainda propor, a partir dos dois poetas, um conceito de contemporâneo que se dê em relação estreita com uma desautorização (como alternativa a um 
paradigma autoral) do histórico, o que, no contexto da Odisseia, se traduz em uma reabertura do problema da retomada, por parte de Ulisses, de seu nome.

Palavras-chave: Odisseia, poesia contemporânea, Ana Martins Marques, Leonardo Gandolfi.

\section{"Nobody" is the name of the author: Leonardo Gandolfi and Ana Martins Marques on the Odyssey}

Filipe Manzoni

This article analyzes the poems of two Brazilian contemporary poets that revisit Homer's Odyssey: Leonardo Gandolfi and Ana Martins Marques. The essay looks into how both writers - Gandolfi in its "Piquenique" and Marques in its "Penélope" - seem to recast the Odyssey as a text in which the tension between the historic and the contemporaneous has not yet been resolved. This understanding will lead to a brief examination (through the works of François Hartog, Erich Auerbach, Haroldo de Campos and Marcos Siscar) of the main role performed by Homer's epic in the notion of literary history and in the concept of history itself. The article's main objective is to articulate the idea of contemporaneity as a de-authorization of a stabilized concept of history through a reopening of Ulysses' journey to recover his name.

Keywords: Odyssey, contemporary poetry, Ana Martins Marques, Leonardo Gandolfi.

\section{"Nadie" es el nombre del autor: Leonardo Gandolfi y Ana Martins Marques sobre Odisea}

Filipe Manzoni

Nuestro trabajo se propone una lectura de dos tramas de la Odisea presentes en las obras de dos poetas contemporáneos, Leonardo Gandolfi y Ana Martins Marques. Nos interesa observar en los dos escritores una problematización de la tensión entre lo histórico y lo contemporáneo: tanto en el bloque "Piquenique", de Gandolfi, como en la serie "Penélope", de Marques, lo que parece estar en juego es un remontaje de la epopeya homérica de modo que la confrontación con lo histórico no esté resuelto. Esta cuestión nos llevará a una reinterpretación de la importancia de la Odisea como modelo para la estructuración de una historia literaria y para el propio concepto de historia en sí a través de autores como François Hartog, Erich Auerbach y, en un contexto más reciente, Haroldo de Campos y Marcos Siscar. Buscamos proponer, a partir de los dos poetas, un concepto de lo contemporáneo que se da en relación estrecha con una desautorización 
(como alternativa a un paradigma autoral) de lo histórico, lo que en el contexto de la Odisea, se traduce en una reapertura del problema de la reutilización, por parte de Ulises, de su nombre.

Palabras clave: Odisea, poesía contemporánea, Ana Martins Marques, Leonardo Gandolfi. 